\title{
Machilin D, a Lignin Derived from Saururus chinensis, Suppresses Breast Cancer Stem Cells and Inhibits NF-KB Signaling
}

\author{
Xing Zhen ${ }^{1,+}$, Hack Sun Choi ${ }^{2, \dagger}{ }^{\dagger}$ Ji-Hyang Kim ${ }^{1}$, Su-Lim Kim ${ }^{1}$, Ren Liu ${ }^{1}$, Bong-Sik Yun ${ }^{3}$ \\ and Dong-Sun Lee ${ }^{1,2,4,5, * \text { (D) }}$ \\ 1 Interdisciplinary Graduate Program in Advanced Convergence Technology and Science, Jeju National \\ University, Jeju 63243, Korea; zhenxing19932013@gmail.com (X.Z.); seogwi12@naver.com (J.-H.K.); \\ ks11101@naver.com (S.-L.K.); liuren0308@gmail.com (R.L.) \\ 2 Subtropical/Tropical Organism Gene Bank, Jeju National University, Jeju 63243, Korea; choix074@jejunu.ac.kr \\ 3 Division of Biotechnology, College of Environmental and Bioresource Sciences, Jeonbuk National University, \\ Gobong-ro 79, Iksan 54596, Korea; bsyun@jbnu.ac.kr \\ 4 Practical Translational Research Center, Jeju National University, Jeju 63243, Korea \\ 5 Faculty of Biotechnology, College of Applied Life Sciences, Jeju National University, SARI, Jeju 63243, Korea \\ * Correspondence: dongsunlee@jejunu.ac.kr \\ $\dagger$ These authors contributed equally to this work.
}

Received: 8 January 2020; Accepted: 3 February 2020; Published: 5 February 2020

\begin{abstract}
Cancer stem cells are responsible for breast cancer initiation, metastasis, and relapse. Targeting breast cancer stem cells (BCSCs) using phytochemicals is a good strategy for the treatment of cancer. A silica gel, a reversed-phase C18 column (ODS), a Sephadex LH-20 gel, thin layer chromatography, and high-performance liquid chromatography (HPLC) were used for compound isolation from Saururus chinensis extracts. The isolated compound was identified as machilin D by mass spectrometry and nuclear magnetic resonance (NMR). Machilin D inhibited the growth and mammosphere formation of breast cancer cells and inhibited tumor growth in a xenograft mouse model. Machilin D reduced the proportions of CD44 ${ }^{+} / \mathrm{CD}^{-} 4^{-}$and aldehyde dehydrogenase 1 (ALDH1)-positive cells. Furthermore, this compound reduced the nuclear localization of the NF- $\mathrm{kB}$ protein and decreased the IL- 6 and IL- 8 secretion in mammospheres. These results suggest that machilin D blocks IL-6 and IL- 8 signaling and induces CSC death and thus may be a potential agent targeting BCSCs.
\end{abstract}

Keywords: breast cancer stem cells (BCSCs); mammospheres; machilin D; NF-kB

\section{Introduction}

Saururus chinensis is a medicinal perennial herbaceous plant that is mainly distributed in moist and wet locations in Japan, southern Korea, North America and China, and has been used in traditional medicine and resources to treat several diseases [1-3]. In cancer chemotherapy, synthetic anticancer agents are effective, but the repeated use of these agents in a complex tumor microenvironment often results in drug resistance [4]. Bioactive chemicals from S. chinensis have received increased attention as an alternative source of materials for cancer therapy. Several compounds, such as lignans, diterpenes, alkaloids, tannins, flavonoids, steroids, and lipids, isolated from $S$. chinensis possess a wide array of pharmacological and biochemical activities [5,6], such as antioxidant [7], antidiabetic [8], anti-inflammatory [1] and anticancer [9] activities.

Breast cancer is one of the most lethal malignant adenocarcinomas and a major cause of cancer-related death in women [10]. Globally, $15 \%-20 \%$ of female breast cancer patients are diagnosed 
with triple negative breast cancer (TNBC) based on the expression of the estrogen receptor, progesterone receptor, and epidermal growth factor receptor 2 [11].

TNBC is characterized by a high risk of recurrence, metastasis, and short progression-free survival (PFS) [12,13]. In recent decades, TNBC cells have shown to have properties similar to breast cancer stem cells (BCSC), and strategies targeting CSCs have shown therapeutic efficacy in preclinical studies of TNBC [14]. CSCs, a subpopulation of tumor cells, are cancer stem-like cells [15]. CSCs can promote oncogenesis to form the tumor bulk, including that of breast cancer, through self-renewal and differentiation [16]. In cancer chemotherapy and radiotherapy, CSCs show multidrug resistance and radio resistance, resulting in cancer recurrence and metastasis $[17,18]$. Therefore, targeting CSCs in cancer therapies is important.

Biomarkers of BCSCs, including CD44 and aldehyde dehydrogenase 1 (ALDH1), can be regulated during cancer progression and metastasis [19]. In TNBC patients, CD44 promotes the transcription of PD-L1, an immune checkpoint, through its cleaved intracytoplasmic domain (ICD) [20]. Inhibition of ALDH1 in breast cancer by curcumin decreased multidrug resistance [21]. The Wnt, Hedgehog, Stat3, Hippo, Notch, and NF-kB signaling pathways regulate CSC stemness and differentiation. Inhibition of BCSCs through targeting these molecular pathways can be an effective tool for cancer therapy $[22,23]$. Stem cell factors such as Sox2 and c-Myc are essential for BCSCs [24]. In the tumor microenvironment, cytokines such as IL-6 regulate the interaction between CSCs and cancer cells. Stat3 and NF-KB signaling stimulates IL-6 and IL-8 production to drive CSC formation [25].

Recently, S. chinensis extracts have been applied to various cancer cell lines, including gastric cancer [9], renal cell carcinoma [26], and hepatocellular carcinoma cell lines [27]. However, no reports have shown the effects of machilin D, a lignin obtained from S. chinensis extracts, on CSC formation. In our study, we purified machilin D from S. chinensis and showed that it suppressed the formation of CSCs. We demonstrated that machilin D inhibits BCSC activity through regulation of IL-6 and IL-8.

\section{Materials and Methods}

\subsection{Reagents}

Open column chromatography was performed using silica gel 60 A (Analtech, Newark, DE) and Sephadex LH 20 (Pharmacia, Uppsala, Sweden). Thin-layer chromatography (TLC) was carried out using a silica gel Kieselgel $60 \mathrm{~F}_{254}$ plate (Merck, Darmstadt, Germany). Preparative high-performance liquid chromatography (HPLC) was conducted on a Shimadzu system (Kyoto, Japan). Machilin D was obtained from the National Institute for Korean Medicine Development (Gyeongsan, Korea). The other chemicals were purchased from Sigma-Aldrich (St. Louis, MO, USA).

\subsection{Plant Material}

S. chinensis was purchased from Handsherb (Yeongcheon, Korea). The voucher specimen (No. 2017_020) is managed in the Department of Biotechnology, Jeju National University, JeJu, South Korea.

\subsection{Extraction and Isolation}

Dry powder of $S$. chinensis was extracted with methanol. The bioassay-based isolation protocol is summarized in Figure 1A. The extracts were vacuum-dried, and the sample was solubilized with $1000 \mathrm{~mL}$ of methanol. The methanol extracts were mixed with water, and the methanol was evaporated. The water-suspended samples were extracted with the same volume of ethyl acetate. The concentrated sample was loaded onto a silica gel column $(3 \times 35 \mathrm{~cm})$ and fractionated with solvent (chloroform-methanol, 30:1) (Figure S1). The twelve parts were divided and assayed for mammosphere formation. The \#5, \#6,\#7, and \#8 fractions potentially inhibited mammosphere formation. The \#5, $\# 6, \# 7$, and \#8 fractions were subjected to preparatory C-18 open columns $(5 \times 7 \mathrm{~cm})$ and eluted with $30 \%, 50 \%, 70 \%$, and $100 \%$ acetonitrile (Figure S2). Four fractions were obtained and assayed for mammosphere formation. The $50 \%$ acetonitrile-eluted fraction inhibited mammosphere formation. 
The $50 \%$ acetonitrile fraction was loaded onto a Sephadex LH 20 open column $(2.5 \times 30 \mathrm{~cm})$ and eluted with four fractions (Figure S3). The four fractions were obtained and assayed for mammosphere formation. Fractions \#1 and \#2 inhibited mammosphere formation. Fractions \#1 and \#2 were isolated using preparatory TLC (glass plate; $20 \times 20 \mathrm{~cm}$ ) and developed in a TLC glass chamber. Individual bands were separated from the silica gel plates using a surgery knife and collected in $15 \mathrm{~mL}$ conical tubes. Each fraction was obtained and assayed for mammosphere formation (Figure S4). Active parts \#4 and \#5 were subjected to HPLC. HPLC analysis was performed using a Shimadzu HPLC 20A system (Shimadzu, Tokyo, Japan). HPLC separation was conducted using an ODS $10 \times 250 \mathrm{~mm}$ C18 column (flow rate; $3 \mathrm{~mL} / \mathrm{min}$ ). The mobile phase was composed of water (solvent $\mathrm{A}$ ) and acetonitrile (solvent B). For gradient elution, solvent B was initially set at $20 \%$, increased to $80 \%$ at $20 \mathrm{~min}$ and increased to $100 \%$ at $40 \mathrm{~min}$. The purified sample was detected at a retention time of $14 \mathrm{~min}$ (Figure S5).

A

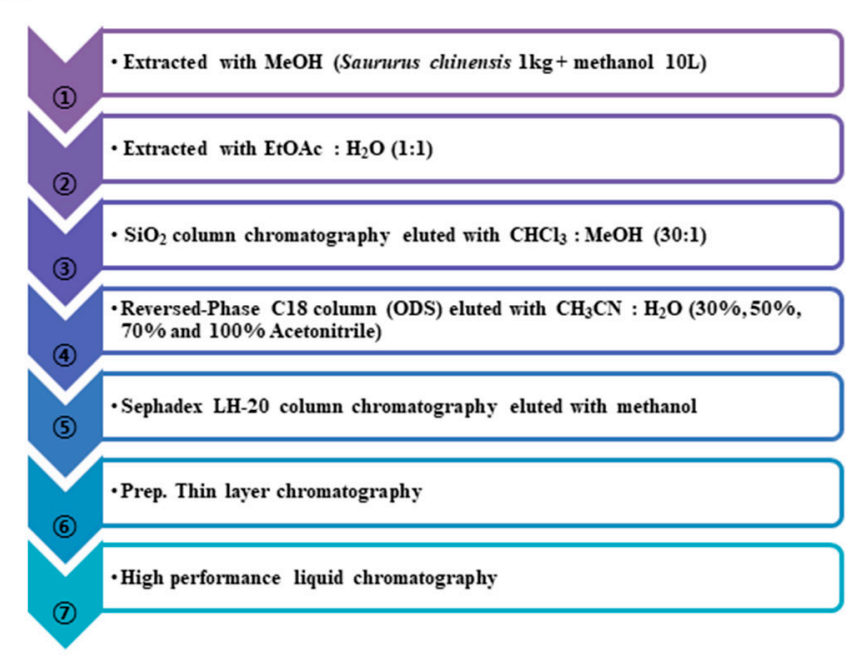

B

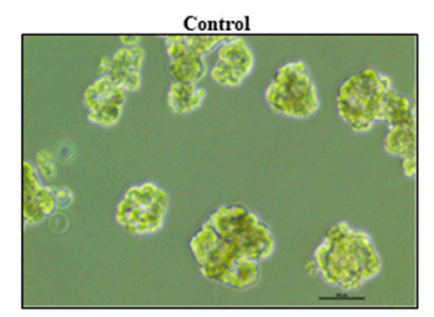

Purified sample

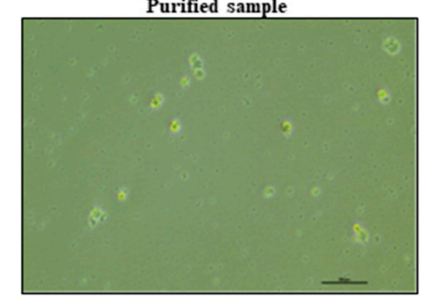

\section{C}

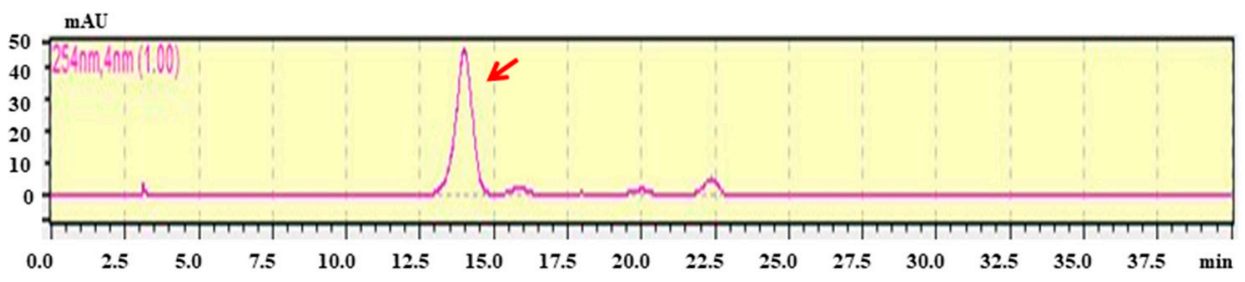

Figure 1. Purification protocol of cancer stem cell (CSC) inhibitors derived from Saururus chinensis and mammosphere formation using purified samples. (A) Flowchart for the isolation of mammosphere inhibitors. (B) Inhibition of mammosphere formation of the high-performance liquid chromatography (HPLC)-purified sample. Cancer cells were treated with HPLC-purified samples. Images show representative mammospheres and were obtained by microscopy (scale bar: $100 \mu \mathrm{m}$ ). (C) HPLC analysis of the isolated inhibitor from S. chinensis.

\subsection{Structural Analysis of the Purified Sample}

The chemical structures of the isolated compounds were determined by mass spectrometry and NMR measurements. The molecular weight was established as $344 \mathrm{kDa}$ by ESI mass spectrometry, which showed quasi-molecular ion peaks at $\mathrm{m} / \mathrm{z} 367.2[\mathrm{M}+\mathrm{Na}]^{+}$in positive mode (Figure $\mathrm{S} 10$ ). The ${ }^{1} \mathrm{H}$ NMR spectrum in $\mathrm{CD}_{3} \mathrm{OD}$ exhibited signals due to six aromatic methine protons at $\delta 6.99,6.97,6.90,6.83$, 6.83 , and 6.76, which are attributable to two 1,2,4-trisubstituted benzenes, two trans-conjugated olefinic methine protons at $\delta 6.32$ and 6.14, two oxygenated methine protons at $\delta 4.63$ and 4.37 , two methoxy groups at $\delta 3.84$ and 3.83 , and two methyl groups at $\delta 1.83$ and 1.05. In the ${ }^{13} \mathrm{C} N M R$ spectrum, 20 carbon peaks included four oxygenated $\mathrm{sp}^{2}$ quaternary carbons at $\delta 151.8,148.8,147.8$, and 147.3; eight $\mathrm{sp}^{2}$ methine carbons at $\delta 131.9,124.9,121.2,120.0,118.2,115.8,111.9$, and 110.9; two sp ${ }^{2}$ quaternary carbons 
at $\delta 133.9$ and 133.7; two oxygenated methine carbons at $\delta 81.9$ and 78.3; two methoxy carbons at $\delta 56.5$ and 56.4; and two methyl carbons at $\delta 18.5$ and 16.5 (see Supplementary Figure S6). All proton-bearing carbons were assigned by the HMQC spectrum, and the ${ }^{1} \mathrm{H}-{ }^{1} \mathrm{H}$ COSY spectrum revealed four partial structures (see Supplementary Figures S7, S8, and S10). Further structural elucidation was performed with the aid of the HMBC spectrum, which showed long-range correlations from the methine proton at $\delta 4.63$ to the carbons at $\delta 133.7,121.2$, and 111.9; from the methine proton at $\delta 6.32$ to the carbons at $\delta 133.9,120.0$, and 110.9; and from the methine proton at $\delta 4.37$ to the carbons at $\delta 147.8$ and 133.7 . Finally, two methoxy groups were connected by the long-range correlations from the methyl protons at $\delta 3.84$ to the carbon at $\delta 151.8$ and from the methyl protons at $\delta 3.83$ to the carbon at $\delta 148.8$ (see Supplementary Figures S9 and S10). Therefore, the structure of the isolated compound was identified as machilin D (Figure 2).

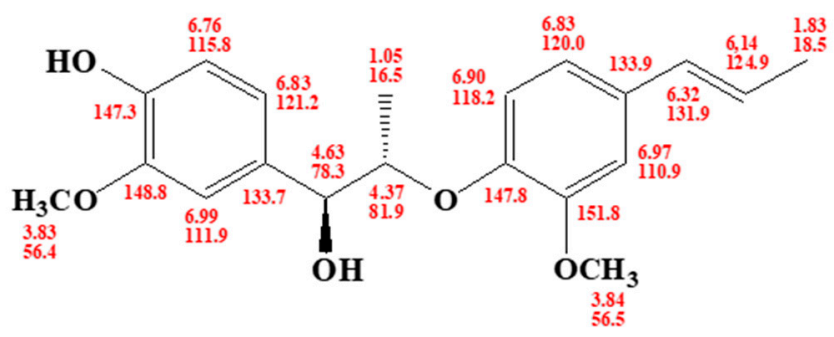

Machilin D $\left(\mathrm{C}_{20} \mathrm{H}_{24} \mathrm{O}_{5}: 344\right)$

Figure 2. Chemical structure of the isolated compound, machilin D, derived from Saururus chinensis.

\subsection{Cell Culture and Mammosphere Formation}

Two breast cancer cell lines, MCF-7 and MDA-MB-231, were obtained from the American Type Culture Collection (Rockville, MD, USA). All human breast cancer cells were maintained in DMEM with 10\% fetal bovine serum (HyClone Fisher Scientific, CA, USA) and 1\% penicillin/streptomycin (HyClone, Thermo Fisher Scientific, CA, USA). Cancer cells $\left(3.5 \times 10^{4}\right.$ or $0.5 \times 10^{4}$ cells) were cultured in an ultralow attachment 6-well plate with a MammoCult ${ }^{\mathrm{TM}}$ culture medium (StemCell Technologies, Vancouver, BC, Canada). All cells were maintained in a humidified $5 \% \mathrm{CO}_{2}$ incubator at $37^{\circ} \mathrm{C}$ for seven days. The mammosphere formation was quantified by the NICE program [28]. Mammosphere formation was estimated by examining the mammosphere formation efficiency (MFE) (\%) [29].

\subsection{Cell Growth Assay}

MDA-MB-231 and MCF-7 cells $\left(1 \times 10^{4}\right.$ cells/well) were seeded in a 96-well plate for $24 \mathrm{~h}$ and treated with various concentrations $(10,25,50,100$, and $200 \mu \mathrm{M})$ of machilin D for $24 \mathrm{~h}$ in a culture medium. Then, growth assay was assessed using the EZ-Cytox kit (DoGenBio, Seoul, Korea) and the OD at a wavelength of $450 \mathrm{~nm}$ was measured using a GloMax ${ }^{\circledR}$ Explorer Multimode microplate reader (Promega, Madison, WI, USA).

\subsection{Colony Formation Assay}

MDA-MB-231 cells $\left(1 \times 10^{3}\right.$ cells/well $)$ were seeded in a 6-well plate, treated with different concentrations of machilin D in DMEM and maintained for seven days at $37^{\circ} \mathrm{C}$ in a $5 \% \mathrm{CO}_{2}$ incubator. The grown colonies were washed with $1 \times$ PBS three times, fixed for 10 min using $3.7 \%$ formaldehyde, treated for $20 \mathrm{~min}$ with $100 \%$ methanol, and stained for $30 \mathrm{~min}$ with $0.05 \%$ crystal violet. The colony formation plate was washed three times using $1 \times$ PBS prior to image capture.

\subsection{Wound-Healing Assay}

MDA-MB-231 cells were plated in a 6-well plate at $1 \times 10^{6}$ cells/well. The cells were cultured overnight and grown into a monolayer. A linear scratch was made by using an SPL Scar ${ }^{\mathrm{TM}}$ scratcher 
(SPL Life Science, Pocheon, Korea). After the cells were washed three times with $1 \times$ PBS, the breast cancer cells were treated with machilin D in a new DMEM. Images of the wounded areas were captured using a light microscope after $24 \mathrm{~h}$.

\subsection{Transwell Assay}

Invasion and migration assays were performed in 12-well hanging inserts with pore polycarbonate membranes (Merck Millipore, Darmstadt, Germany) coated with (invasion) or without (migration) a growth factor-reduced Matrigel matrix basement (BD, San Jose, CA, USA) following the manufacturer's protocol. Two hundred microliters of MDA-MB-231 cell suspensions in 1\% FBS DMEM was added to the upper chamber $\left(1 \times 10^{5}\right.$ cells/chamber). The bottom chamber was filled with $800 \mu \mathrm{L}$ of DMEM containing $10 \%$ FBS as a chemoattractant. The cells were maintained for two days at $37{ }^{\circ} \mathrm{C}$ in a $5 \% \mathrm{CO}_{2}$ incubator. The cells that passed through the membrane to the lower surface were fixed with $3.7 \%$ paraformaldehyde and stained with $0.05 \%$ crystal violet. The images were captured with a light microscope.

\subsection{Flow Cytometric Analysis and ALDH1 Activity}

After incubation with machilin D for $24 \mathrm{~h}$, the cancer cells were harvested and dissociated using $1 \times$ trypsin/EDTA. We used a previously described method [24]. A total of $1 \times 10^{6}$ cells were cultured with anti-CD44-FITC and anti-CD24-PE antibodies (BD, San Jose, CA, USA) on ice for $30 \mathrm{~min}$. The cancer cells were centrifuged and washed three times with a $1 \times$ FACS buffer and analyzed by an Accuri C6 cytometer (BD, San Jose, CA, USA). The ALDH1 activity was assayed using an Aldefluor ${ }^{\mathrm{TM}}$ assay kit (StemCell Technologies, Vancouver, BC, Canada). We used a previously described method [24]. The breast cancer cells were treated with machilin D $(50 \mu \mathrm{M})$ for $24 \mathrm{~h}$ and reacted in ALDH assay buffer at $37^{\circ} \mathrm{C}$ for $20 \mathrm{~min}$. The ALDH-positive cells were examined by an Accuri C6 cytometer (BD, San Jose, CA, USA).

\subsection{Quantitative Measurement of Human Cytokines}

Human cytokines were measured using the BD ${ }^{\mathrm{TM}}$ Cytometric Bead array (CBA) human inflammatory cytokine assay kit (BD, San Jose, CA, USA). MDA-MB-231 cell mammospheres were seeded in ultralow attachment 6-well plates containing $2 \mathrm{~mL}$ of a complete MammoCult ${ }^{\mathrm{TM}}$ medium for five days and incubated with machilin $\mathrm{D}(50 \mu \mathrm{M})$ for two days. We followed the manufacturer's protocol. The IL-6 and IL-8 levels in the cultured media were assayed by a BD ${ }^{\text {TM }}$ CBA human inflammatory cytokine assay kit. Fifty microliters of mixed capture beads, $50 \mu \mathrm{L}$ of cultured or standard medium and $50 \mu \mathrm{L}$ of PE detection reagent were added to each assay tube. The samples were incubated at room temperature for $3 \mathrm{~h}$, protected from light, washed with a washing buffer and centrifuged. After the washes, $300 \mu \mathrm{L}$ of washing buffer was used to resuspend the pellet, and the samples were analyzed using flow cytometry.

\subsection{Gene Expression Analysis}

Total RNA of the cancer cells was extracted and purified, and real-time RT-quantitative PCR was assayed using a real-time one-step RT-qPCR kit (Enzynomics, Daejeon, Korea). We used a previously described method [30]. The specific primers are described in Table S1.

\subsection{Immunofluorescence (IF) Staining Assay}

Breast cancer cells were fixed with $4 \%$ paraformaldehyde for $30 \mathrm{~min}$, permeabilized with $0.5 \%$ Triton X-100 for 10 min, blocked with 3\% bovine serum albumin (BSA) for 30 min, and stained with mouse anti-p65, LF-MA30327 (AbFrontier, Seoul, Korea), followed by secondary anti-mouse Alexa 488 antibody, A32723 (ThermoFisher, Walthan, MA, US). We used nonspecific signal conditions to ensure the specificity of the primary antibodies for IF. Finally, the nuclei were stained with DAPI, and p65 was visualized with a fluorescence microscope (Lionheart, Biotek, VT, USA). 


\subsection{Western Blot Analysis}

Cells and mammospheres were lysed in ice in a RIPA buffer (1\% NP-40, $150 \mathrm{mM} \mathrm{NaCl}, 1 \%$ sodium deoxycholate, $0.1 \%$ SDS, $25 \mathrm{mM}$ Tris- $\mathrm{HCl} \mathrm{pH}$ 7.6). The lysates were centrifuged and the cytoplasmic extract was collected in the resulting supernatant. Samples $(20 \mu \mathrm{g} / 10 \mu \mathrm{L})$ were prepared from the cells and mammospheres. After electrophoresis on a 12\% SDS-PAGE gel, the proteins were transferred to a polyvinylidene fluoride (PVDF) membrane (Millipore, Burlington, MA, USA). The membrane was incubated in an Odyssey blocking buffer at room temperature for $1 \mathrm{~h}$ and then incubated overnight with primary antibodies. The antibodies were p65, LF-MA30327; GAPDH, LF-PA0018; Oct4, LF-MA30482 (AbFrontier, Seoul, Korea); LaminB, sc-365962; Nanog, sc-293121; Sox2, sc-365923 (Santa Cruz Biotechnology, Dallas, TX, USA); and c-Myc, 551101 (BD, San Jose, CA, USA). After the membranes were washed, they were incubated with IRDye 680RD and 800W secondary antibodies at room temperature for $1 \mathrm{~h}$, and the signals were determined with an Odyssey CLx machine (Li-Cor, Lincoln, NE, USA).

\subsection{Electrophoretic Mobility Shift Assay (EMSA)}

EMSAs were performed with an Odyssey Infrared EMSA kit (Li-Cor, Lincoln, NE, USA) according to the manufacturer's instructions. The IRD700-labelled strands of the NF- $\mathrm{KB}$ oligonucleotide (5'-/5IRD700/ AGTTGAGGGGACTTTCCCAGGC-3' and 5'-/5IRD700/GCCTGGGAAAGTCCCCTCAACT-3') were annealed. The IRDye 700 NF-KB oligonucleotide was incubated with nuclear extracts in a final volume of $20 \mu \mathrm{L}$ at room temperature for $30 \mathrm{~min}$. The samples were electrophoresed on a $6 \%$ polyacrylamide nondenaturing gel, and the EMSA data were visualized by an Odyssey CLx machine.

\subsection{Xenograft Transplantation}

Twelve female nude mice were injected with two million MDA-MB-231 cells and injected with/without machilin D $(10 \mathrm{mg} / \mathrm{kg})$. The tumor volumes were estimated for 30 days using the formula $\left(\right.$ width $^{2} \times$ length)/2. The mouse experiments were performed as described previously [31]. Animal care and animal experiments were performed in accordance with protocols approved by the Institutional Animal Care and Use Committee (IACUC) of Jeju National University. Female nude mice (four weeks old) were purchased from OrientBio (Seoul, South Korea) and kept in mouse facilities for one week.

\subsection{Statistical Analysis}

All data were analyzed with the GraphPad Prism 7.0 software (GraphPad Prism, Inc., San Diego, CA, USA). All data are reported as the mean \pm standard deviation (SD). Data were analyzed by using one-way ANOVA. $P$-values less than 0.05 were considered significant.

\section{Results}

\subsection{Isolation of a BCSC Inhibitor from S. chinensis}

A mammosphere formation assay was performed to screen human BCSC inhibitors using the methanol extracts of $S$. chinensis. The mammosphere assay-based isolation protocol is summarized in Figure 1A. The purified sample inhibited the CSCs (Figure 1B). The extracted samples were purified using organic solvent extraction, silica gel, reversed-phase C18 open column (ODS), a Sephadex LH-20 gel, preparatory TLC, and preparatory HPLC. The isolated compounds were analyzed by preparatory HPLC (Figure 1C). The isolated compound of interest was identified as machilin D (Figure 2).

\subsection{Machilin D Suppresses Growth and Mammosphere Formation}

To determine whether machilin $\mathrm{D}$ has a potent inhibitory effect on human cancer cells, we first tested the antiproliferative effect on machilin D at various concentrations in MCF-7 and MDA-MB-231 cells. We observed an antiproliferative effect of $\geq 25 \mu \mathrm{M}$ machilin $\mathrm{D}$ after one day of stimulation 
(Figure 3A,B). To determine whether machilin D can inhibit mammosphere formation, we treated the mammospheres with machilin D. As shown in Figure 3C,D, machilin D not only decreased the sphere number by $90 \%$ but also reduced the size of the mammospheres. Treatment with machilin D suppressed migration, invasion, and colony formation (Figure 3E-G). These results showed that machilin D suppresses mammosphere formation and growth, as well as migration, invasion, and colony formation.

A

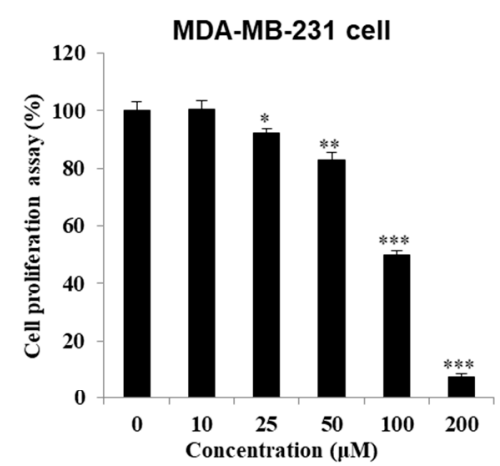

C

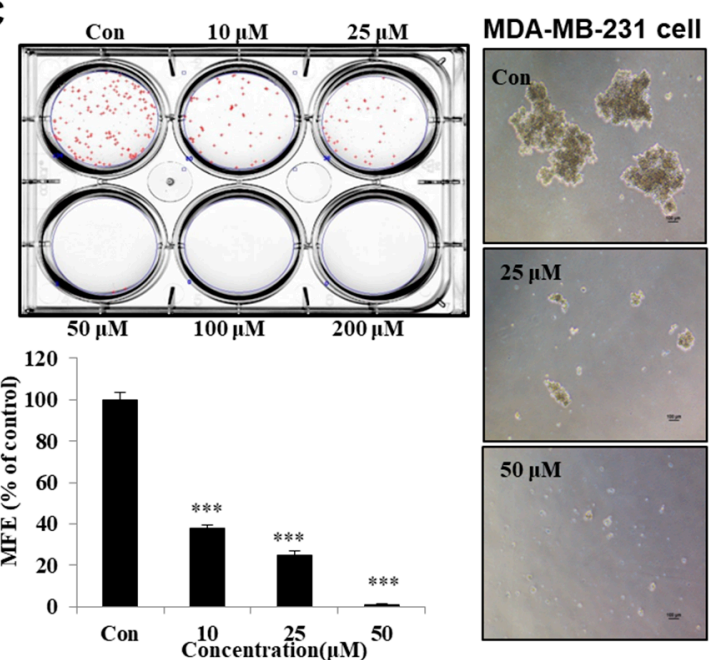

B

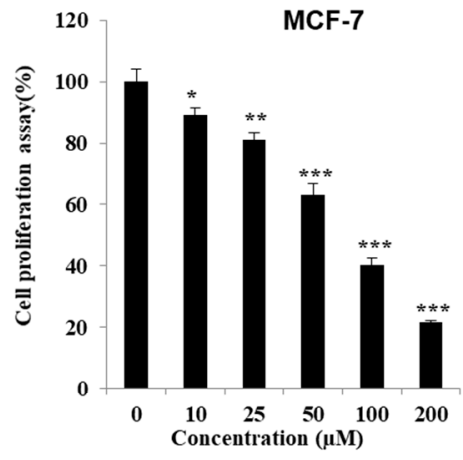

D
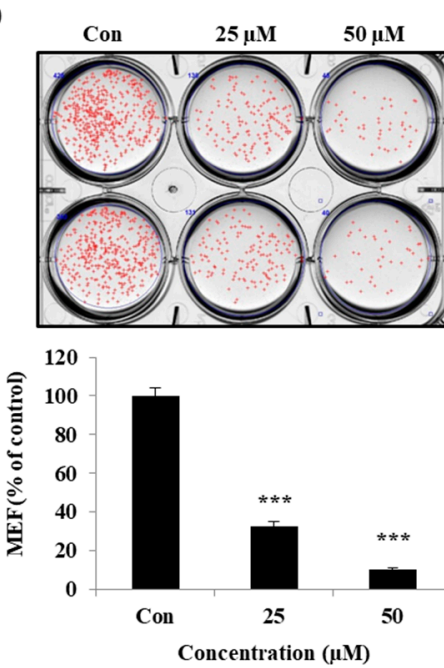

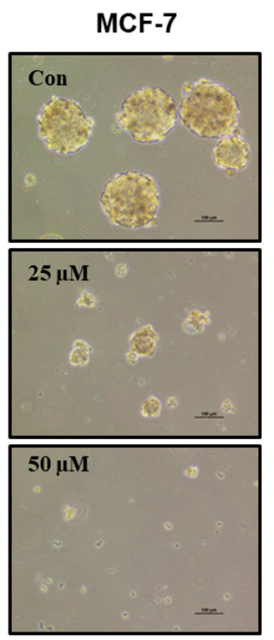

$\mathbf{E}$

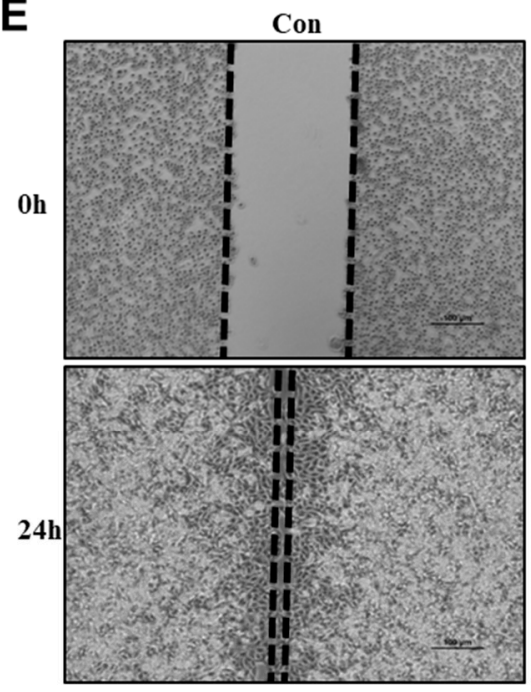

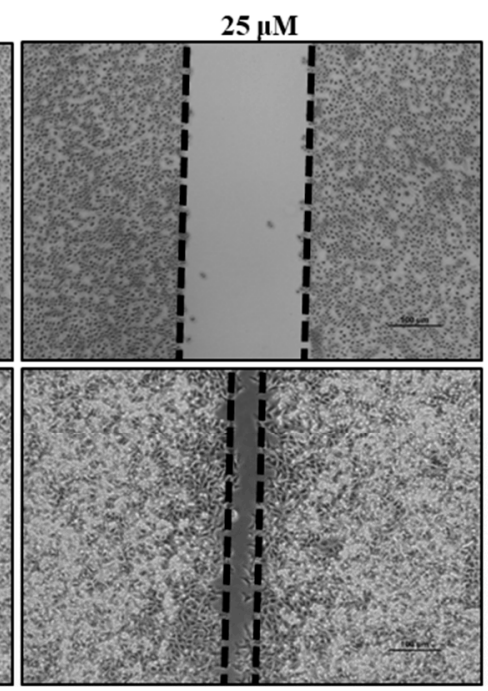

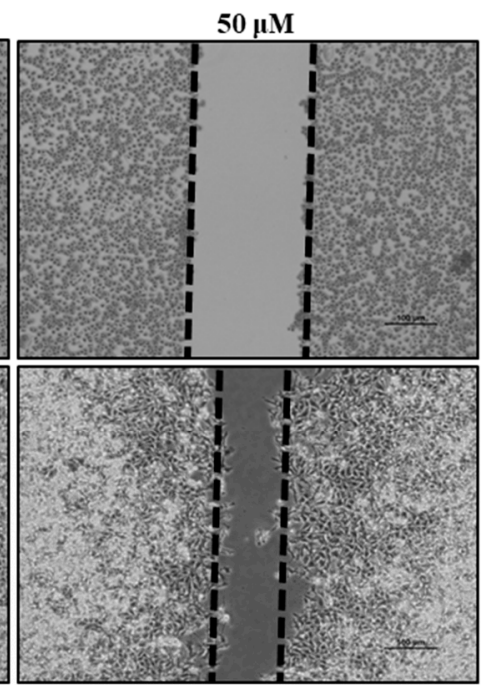

Figure 3. Cont. 
$\mathbf{F}$

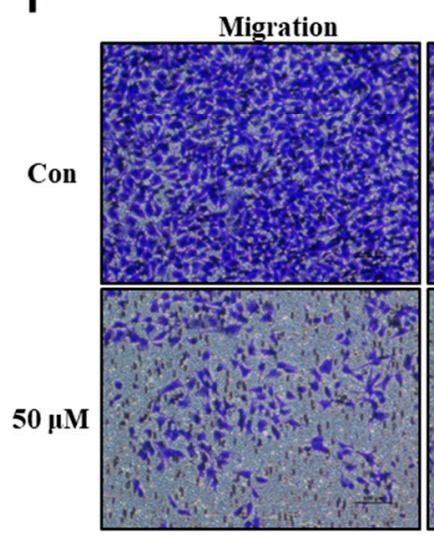

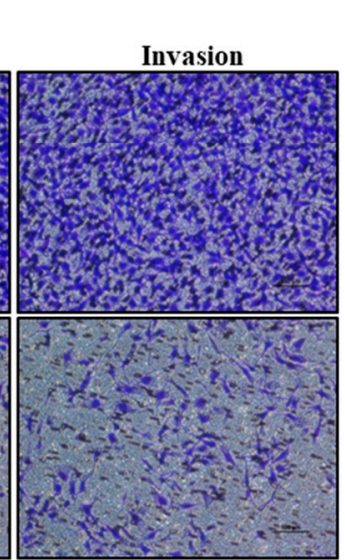

G

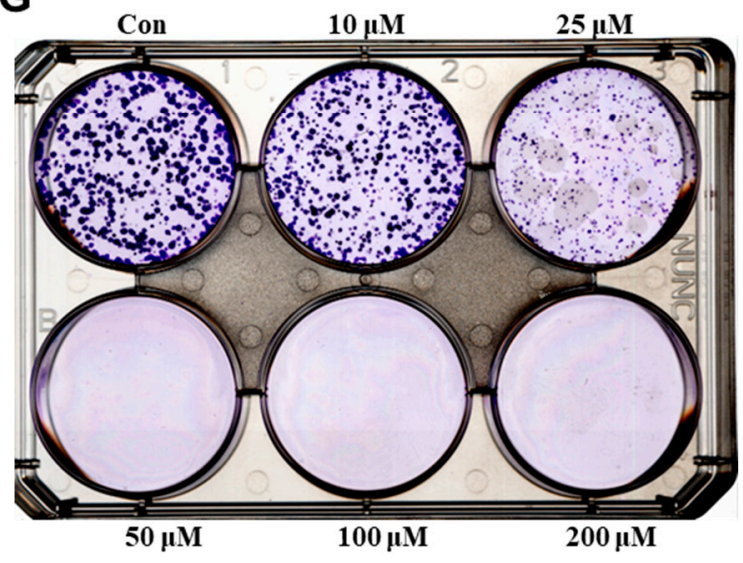

Figure 3. The effect of machilin D on cell growth and mammosphere formation. (A) MDA-MB-231 cells were treated with machilin D for $24 \mathrm{~h}$ in a culture medium. The cell growth assay using machilin D was measured with an EZ-Cytox kit. (B) Breast cancer MCF-7 cells were treated with various concentrations of machilin D for $24 \mathrm{~h}$ in a culture medium. The cell proliperation of the MCF-7 cells was measured with an EZ-Cytox kit. (C,D) Machilin D inhibits the formation of mammospheres. For the establishment of mammospheres, $1 \times 10^{4}$ MDA-MB-231 cells and $4 \times 10^{4}$ MCF-7 cells were seeded in ultralow 6-well plates using a CSC culture media. The mammospheres were incubated with increasing concentrations of machilin D or DMSO for seven days. Images showing representative mammospheres were obtained by microscopy (scale bar: $100 \mu \mathrm{m}$ ). The mammosphere formation efficiency (MFE) was examined. (E) Effect of machilin D on the migration of the breast cancer cells. The migration with/without machilin D was photographed at 0 and $24 \mathrm{~h}$ (scale bar: $100 \mu \mathrm{m}$ ). (F) Transwell assays were performed to determine the cell migration (without Matrigel) and invasion (with Matrigel) of the MDA-MB-231 cells exposed to machilin D (scale bar: $100 \mu \mathrm{m}$ ). (G) Machilin D inhibits the colony formation of the cancer cells. The cancer cells were incubated in 6-well plates and treated with machilin D. Representative data were collected. The data from triplicate experiments are represented as the mean \pm SD; ${ }^{*} p<0.05 ;{ }^{* *} p<0.01 ; * * * 00.001$.

\subsection{Machilin D Suppresses Tumor Growth}

As machilin D has antiproliferative effects in breast cancer, we examined whether this compound reduces tumor growth using an in vivo mouse model. The body weights of the control and machilin D-treated mice did not change (Figure 4A). The tumor volume of the machilin D-treated mice was lower than that of the control mice (Figure 4B). The tumor weights of the machilin D-treated mice were significantly lower than those of the control mice (Figure 4C,D). Our results showed that machilin D effectively decreased tumor growth in a mouse model. 

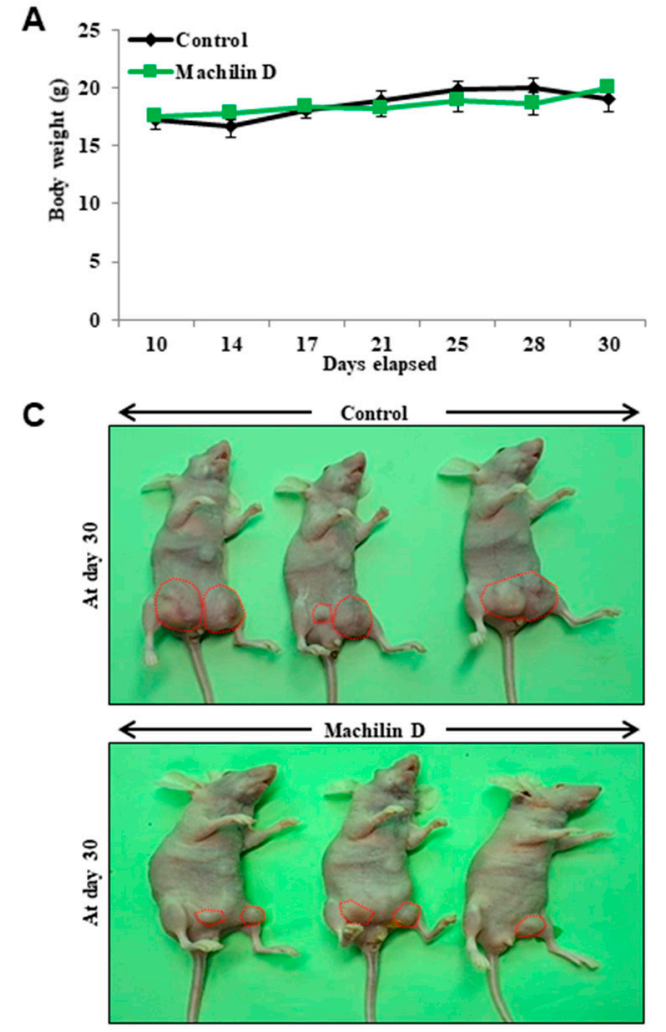

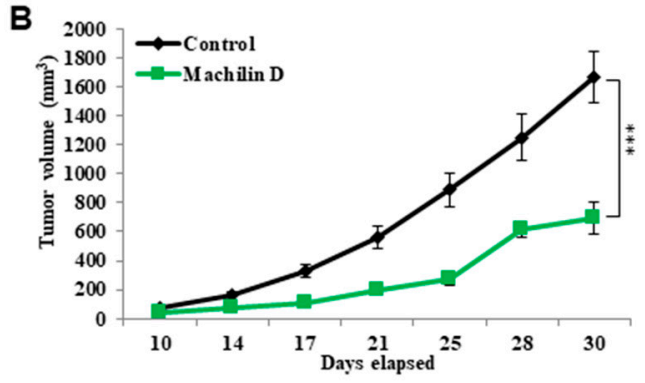

D
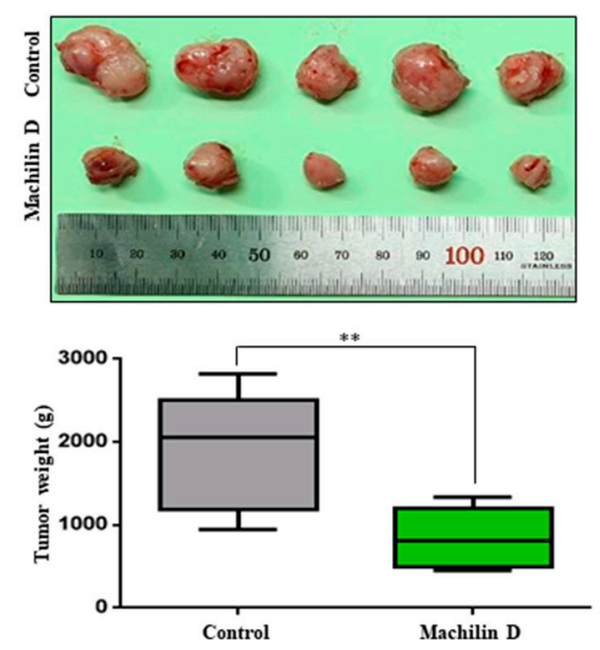

Figure 4. The effect of machilin D on the tumor growth in a xenograft model. MDA-MB-231 cells (2 $\times 10^{6}$ cells/mouse) were inoculated into the mammary fat pad of female nude mice and treated with machilin D or DMSO ( $\mathrm{n}=6)$. The drug concentration was $10 \mathrm{mg} / \mathrm{kg}$. (A) The body weights of the machilin D-treated group were comparable with those of the control group. (B) The tumor volume was calculated as (width ${ }^{2} \times$ length) $/ 2$ at the indicated time points. (C) The mouse images of the control and machilin D-treated groups were captured with a camera at day 30. (D) Tumor weights of the control and machilin D-treated mice were assayed after sacrifice at day 30 . The data are presented as the mean $\pm \mathrm{SD}$ of three independent experiments. ${ }^{* *} p<0.05 ;{ }^{* * *} p<0.01$ versus the DMSO-treated control group indicated significant differences.

\subsection{Machilin D Decreases CD44 ${ }^{\text {high }} / C D 24^{\text {low }}$-expressing and ALDH-positive Cancer Cells}

$\mathrm{CD}_{4} 4^{+} / \mathrm{CD} 24^{-}$and ALDH1 expression are markers of BCSCs. The CD44 ${ }^{+} / \mathrm{CD} 24^{-}$population of breast cancer cells was assayed under machilin D treatment. Machilin D reduced the CD $44^{+} / \mathrm{CD}^{-} 4^{-}$ cell fraction from $17.8 \%$ to $11.2 \%$ (Figure $5 \mathrm{~A}$ ). We also tested the killing effects of machilin D on ALDH-positive cancer cells. Machilin D reduced the ALDH-positive cell fraction from 7.8\% to 4.2\% (Figure 5B). Our results showed that machilin D specifically inhibits mammosphere formation. 
A

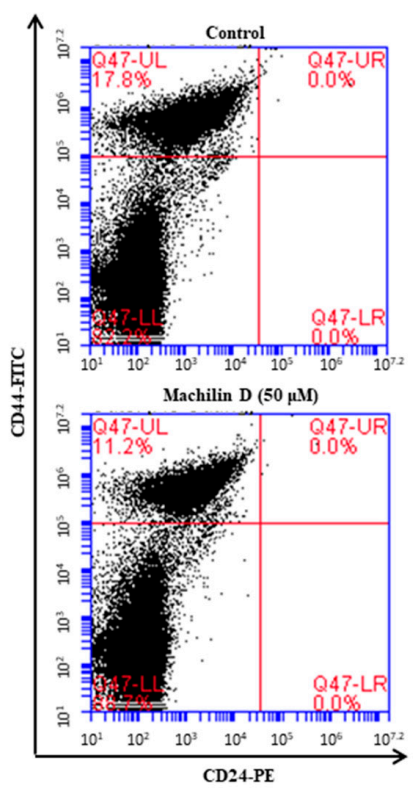

B

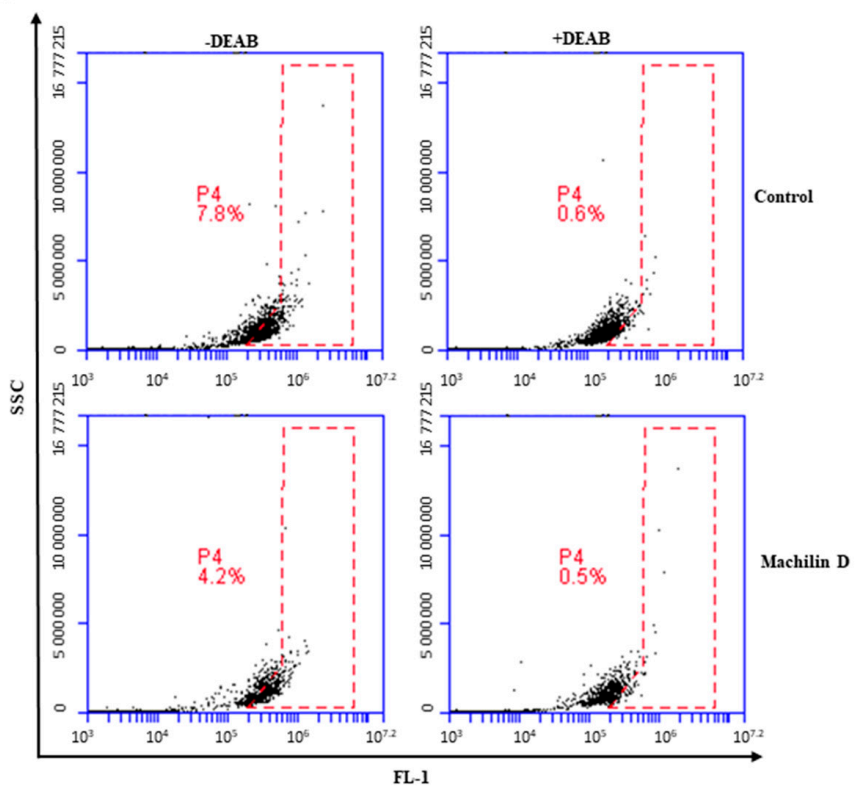

Figure 5. The effect of machilin D on the CD44 $4^{\text {high }} / \mathrm{CD} 24^{\text {low }}$ and Aldehyde dehydrogenase (ALDH)positive cell proportions. (A) The CD44 ${ }^{\text {high }} / \mathrm{CD} 24^{\text {low }}$ cell population of the MDA-MB-231 cells treated with machilin $\mathrm{D}(50 \mu \mathrm{M})$ or DMSO for $24 \mathrm{~h}$ was analyzed by flow cytometry. The gating was based on binding of a control antibody (red cross). (B) Machilin D decreased the ALDH-positive cell population detected by the Aldefluor kit. Cancer cells were treated with machilin D $(50 \mu \mathrm{M})$ for $24 \mathrm{~h}$ and subjected to Fuorescence-activated cell sorting (FACS) analysis. Representative flow cytometric data are shown. The right panel shows the ALDH-positive population with the ALDH inhibitor DEAB, and the left panel represents the ALDH-positive population without DEAB.

\subsection{Machilin D inhibits p65 Nuclear Translocation in BCSCs}

To investigate the cellular mechanism of machilin D in mammospheres, we determined the localization of NF-KB p65 in mammospheres. We observed that the nuclear level of p65 was significantly decreased following machilin D treatment (Figure 6A). Furthermore, an IF assay of p65 in the MDA-MB-231 cells indicated that the levels of nuclear p65 in the machilin D-treated cells were lower than those in the untreated cells (Figure 6B). Caffeic acid phenethyl ester (CAPE), an inhibitor of the NF- $\mathrm{KB}$ signaling pathway that blocks the nuclear translocation of p65, was used to evaluate mammosphere formation [32]. Treatment with machilin D and CAPE (Figure 6C,D), which reduced nuclear p65, blocked mammosphere formation. In conclusion, our data showed that NF- $\mathrm{B}$ signaling regulates mammosphere formation.

\subsection{Machilin D Reduces the Secretion of IL-6 and IL-8 in the Mammospheres and Regulated NF- $k B$ Activity}

To determine the cellular mechanism of machilin $\mathrm{D}$, we have analyzed the localization of NF- $\mathrm{KB}$ p65 and secretion of IL- 6 and IL- 8 of the mammospheres treated with machilin D. NF- $\mathrm{kB}$ DNA binding was assessed in the nuclear extracts treated with machilin D by an IRDye 700-NF- $\mathrm{kB}$ probe. Machilin $\mathrm{D}$ decreased the binding ability of the NF- $\mathrm{kB}$ probe (Figure $6 \mathrm{E}, \# 3$ ). The specificity of the NF- $\mathrm{kB}$ probe was demonstrated using $100 \times$ unlabeled self-competitor (Figure $6 \mathrm{E}$, \#4) and $100 \times$ mutated-NF- $\mathrm{kB}$ competitor (Figure 6E, \#5). Machilin D inhibited the binding ability of NF-kB. Secreted IL-6 and IL-8 are important factors in BCSC survival [33,34]. Real-time RT-qPCR was performed to analyze the transcript levels of IL-6 and IL-8 under machilin D treatment. The data showed that machilin D reduces the transcript levels of IL-6 and IL-8 (Figure 6F). We performed a culture medium cytokine profiling of the mammospheres after machilin D treatment to test the levels of the IL- 6 and IL-8 cytokines. The cytokine profiling data showed that machilin D reduced the levels of extracellular IL-6 and IL-8 (Figure 6G). 
A
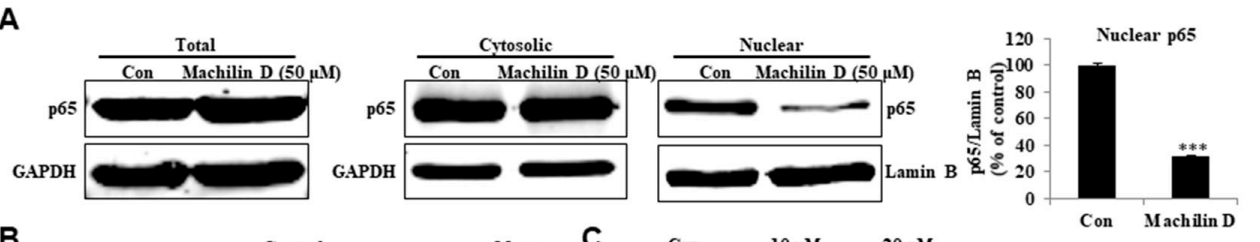

B
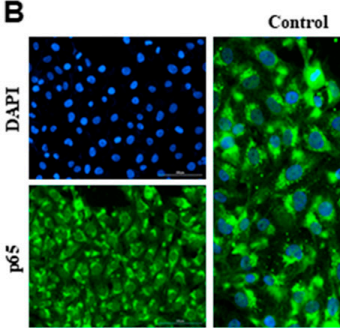

C

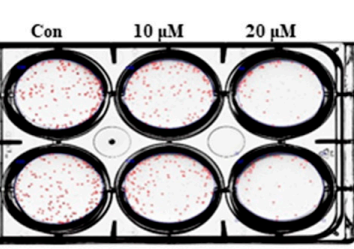

Con Machilin D
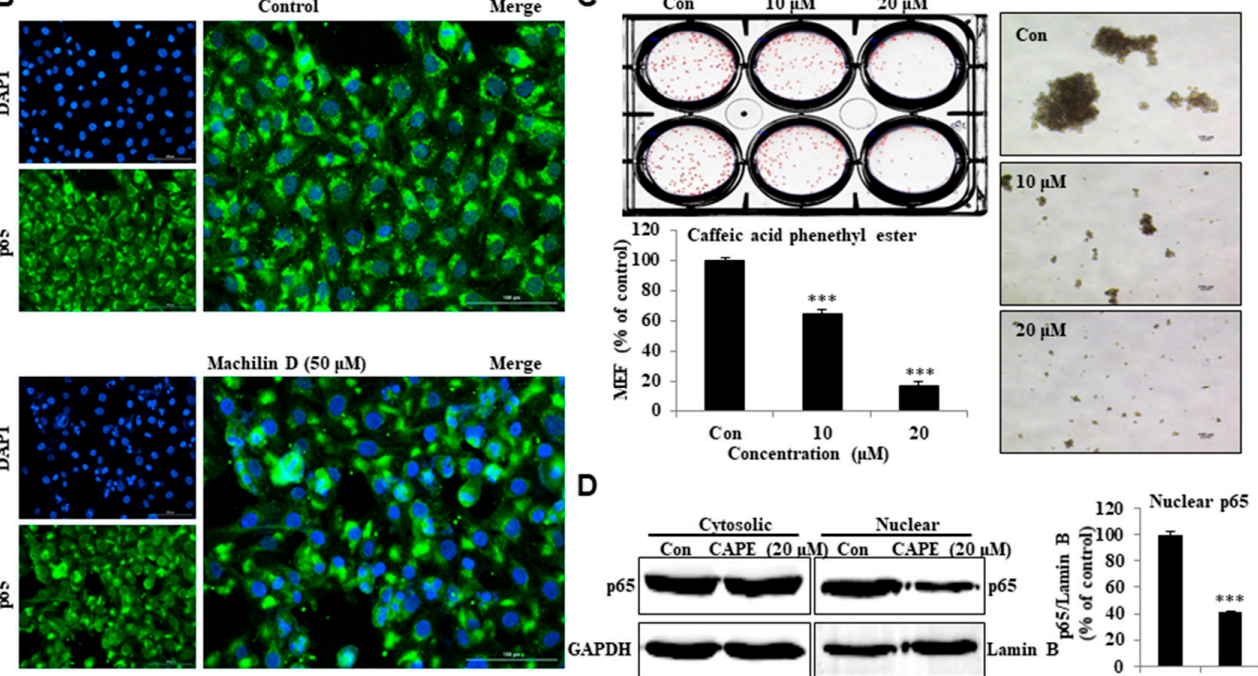

D
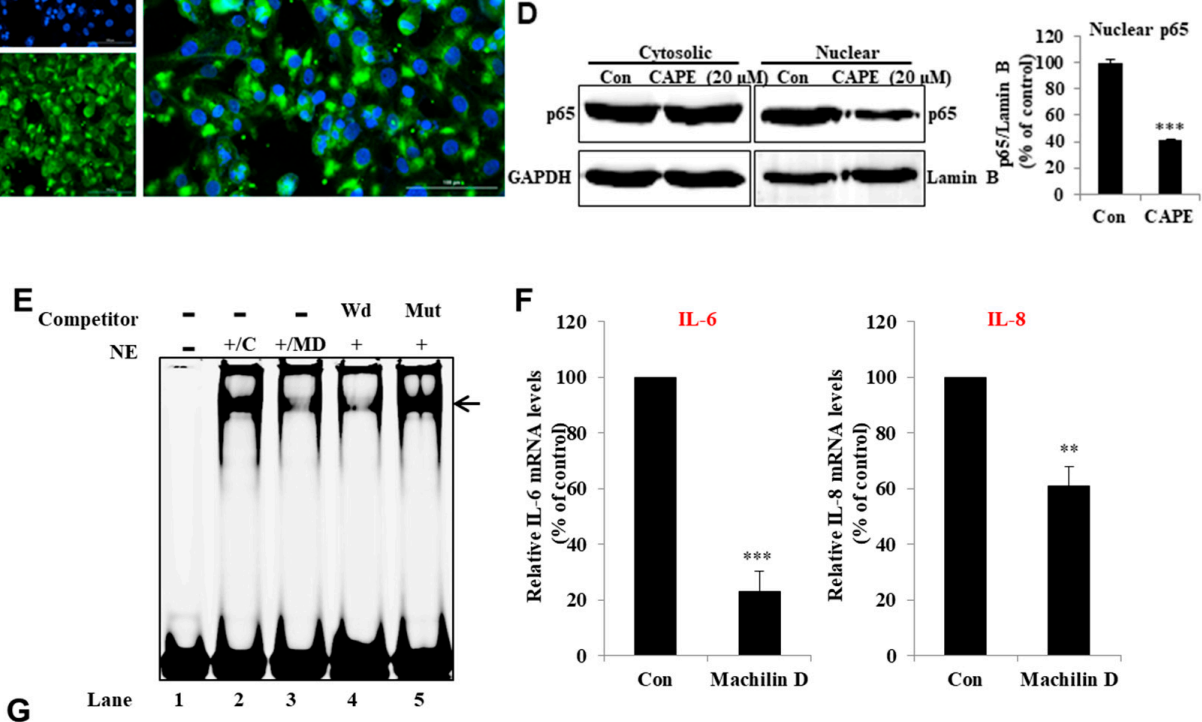

G

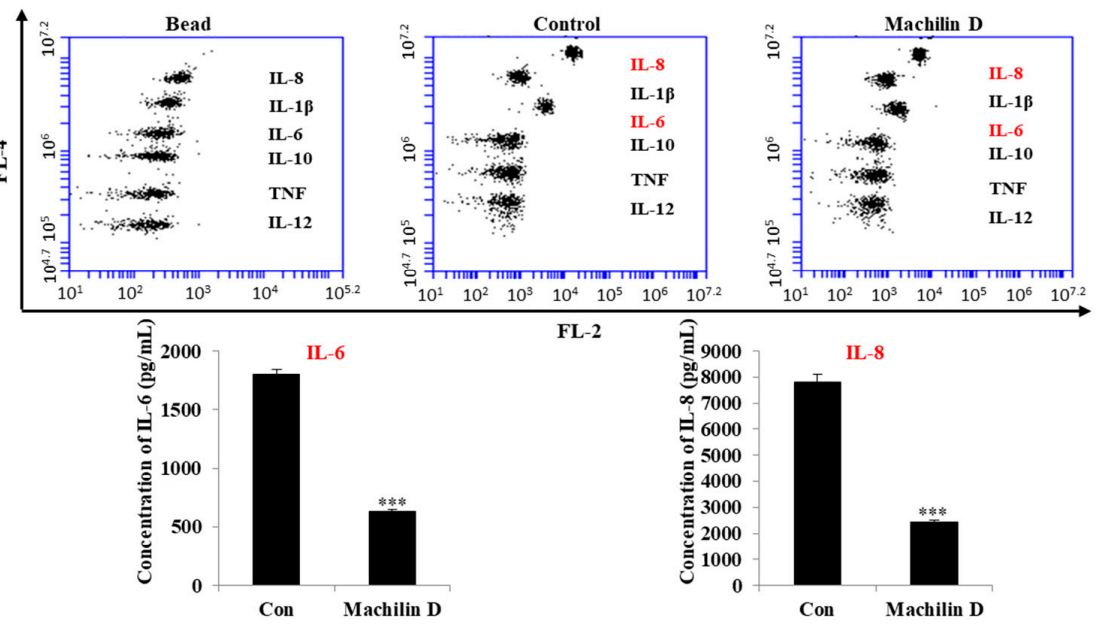

Figure 6. Machilin D regulates the location of NF-kB p65 and secretion of IL-6 and IL-8. (A) The levels of p65 in the total, cytosolic, and nuclear proteins were measured in the MDA-MB-231 cells after treatment with machilin D for $24 \mathrm{~h}$ using western blot analyses. (B) Immunofluorescence (IF) analysis of p65 (green) expression and localization in the breast cancer cells under machilin D treatment. (C) The effect of caffeic acid phenethyl ester (CAPE), an inhibitor of NF- $\mathrm{B}$, on mammosphere formation. (D) The p65 levels in the cytosolic and nuclear proteins were measured in the MDA-MB-231 cells after 
treatment with CAPE for $24 \mathrm{~h}$ using western blot analyses. (E) Electrophoresis Mobility Shift Assays (EMSAs) of mammosphere nuclear proteins after treatment with machilin $\mathrm{D}$. The nuclear extracts were reacted with the NF- $\mathrm{BB}$ probe and were analyzed by $6 \%$ native PAGE. Lane 1 : NF- $\mathrm{kB}$ probe; lane 2 : Nuclear extracts with the NF- $\kappa B$ probe; lane 3: Machilin D-treated nuclear proteins with the NF- $\mathrm{kB}$ probe; lane 4: Nuclear proteins incubated with the self-competitor $(100 \times)$ oligo; lane 5 : Nuclear extracts incubated with the mutated-NF- $\mathrm{kB}(100 \times)$ probe. The arrow indicates the DNA/NF- $\mathrm{kB}$ complex in the mammosphere nuclear lysates. (F) Transcriptional expression of the IL-6 and IL-8 genes was determined in the machilin D-treated mammospheres using specific primers. (G) Cytokine profile assay of the conditioned media and the machilin D-treated media using specific antibodies and cytokine beads. The data are presented as the mean \pm SD of three independent experiments. ${ }^{* *} p<0.05 ;{ }^{* *} p<0.01$ versus the DMSO-treated control group indicated significant differences.

\subsection{Machilin D Inhibits the Expression of Stem Cell Marker Genes and the Growth of Mammospheres}

To determine whether machilin D inhibits stem cell marker genes, we examined the protein levels of these genes. Machilin D treatment decreased the expression of stem cell markers in human breast CSCs (Figure 7A). To confirm that machilin D reduced mammosphere growth, we incubated mammospheres with machilin D and quantified the cancer cells derived from mammospheres. Machilin $\mathrm{D}$ induced cell death and caused a substantial decrease in mammosphere growth (Figure 7B). Our data suggested that machilin D inhibits the growth of BCSCs through NF- $\mathrm{kB}$ inhibition and reductions in IL-6 and IL-8.

A
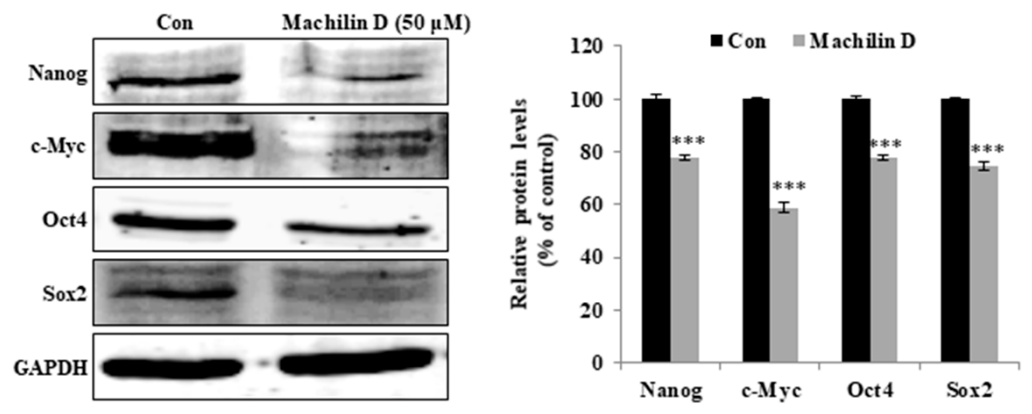

$\mathbf{B}$

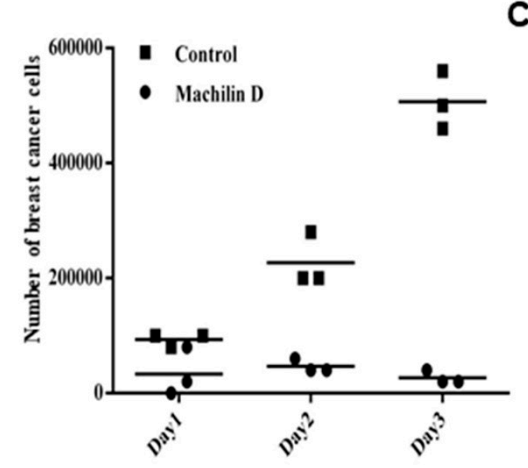

C

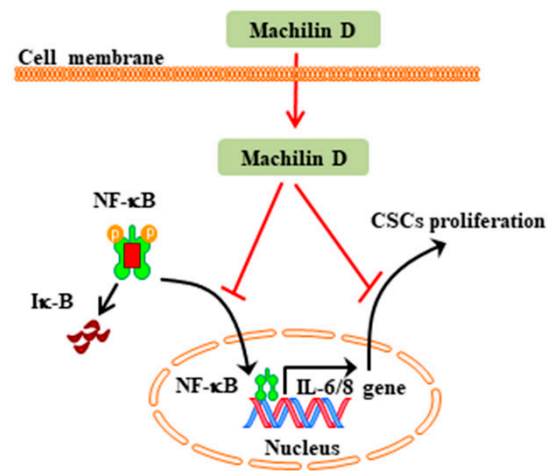

Figure 7. The effect of machilin D on the expression of CSC marker proteins and mammosphere growth. (A) Immunoblot analysis of the Nanog, c-Myc, Oct4, and Sox2 proteins in the mammospheres after treatment with machilin D for two days. (B) Machilin D inhibits mammosphere growth. Mammospheres with/without machilin D were dissociated into single cells and plated in $6 \mathrm{~cm}$ dishes in equal numbers. One, two, and three days later, the cells were counted. (C) The proposed model of CSC death through the NF- $\mathrm{kB}$ inhibition and IL- 6 and IL-8 signaling pathways by machilin D is shown. The data from triplicate experiments are represented as the mean $\pm \mathrm{SD} .{ }^{* * *} p<0.05$ versus the DMSO-treated control group indicated significant differences. 


\section{Discussion}

Breast tumors are the most frequently diagnosed malignancy in breast tissue and are a major cause of cancer-related death in women [35]. Although the mortality of breast cancer has been stabilized, the morbidity is increasing, especially in premenopausal women with a poor prognosis and unfavourable molecular subtypes compared with postmenopausal patients older than 40 years [36]. According to the biological characteristics of the tumor, including stage, grade and genetic status, major treatments, such as surgical resection, chemotherapy and radiotherapy, are selected to increase the survival rate of breast cancer patients $[37,38]$. The limitation of current therapeutic strategies for patients who display metastasis or experience recurrence has been attributed to the existence of CSCs $[39,40]$. Increasing evidence has shown that BCSCs characterized by high expression of ALDH and a CD44 $4^{\text {high }} / \mathrm{CD} 24^{\text {low }}$ phenotype have multiple drug resistance mechanisms [41]. CSCs derived from cancer cell lines are used as potential targets for breast cancer therapies [42].

Recently, several reports have demonstrated the anticancer effects of $S$. chinensis extracts $[26,43]$. However, the potential of machilin D, a lignin derived from S. chinensis, in cancer or CSC treatment has not been investigated. Our results showed that machilin D has potential as an anti-CSC agent. Machilin D inhibited the growth of breast cancer cells and mammospheres (Figure 3). Metastasis is known to cause high rates of recurrence and mortality in cancer patients [44,45]. Machilin D inhibited the migration, invasion, and colony formation of the breast cancer cells (Figure 3). Furthermore, machilin D inhibited tumor growth (Figure 4).

Current chemotherapeutics target CSCs, inducing cancer relapse. Three subtypes of BCSCsmesenchymal-like CD44 $4^{\text {high }} / \mathrm{CD} 24^{\text {low }}$ CSCs, epithelial-like $\mathrm{ALDH}^{+} \mathrm{CSC}$ s, and $\mathrm{ALDH}{ }^{+} / \mathrm{CD}_{4} 4^{\text {high }} / \mathrm{CD} 24^{\text {low }}$ CSCs-have been identified [46]. Machilin D decreased the CD44high/CD24 $4^{\text {low }}$ and ALDH-positive populations (Figure 5). NF- $\mathrm{kB}$ signaling is involved in the regulation of inflammation, immunity, cell survival, and growth through the transcription of target genes such as cytokines and growth factors [47]. Constitutively activated NF- $\mathrm{KB}$ signaling is present in many types of solid tumors and mediates cancer cell growth and metastasis [48]. During CSC growth as multicellular spheres, constitutive NF- $\mathrm{kB}$ signaling was shown to be activated along with upregulation of NF- $k B-d e p e n d e n t$ genes [49]. As the NF- $\mathrm{KB}$ signal is important for BCSCs and S. chinensis extracts showed significant anti-inflammatory effects $[1,50]$, we examined the expression level and localization of the p65 subunit. Machilin D inhibited mammosphere formation through the NF- $\mathrm{kB}$ signaling pathway (Figure 6). CAPE, an inhibitor of NF- $\mathrm{KB}$, decreased p65 translocation and inhibited mammosphere formation (Figure 6).

Several cytokines regulate the NF- $\mathrm{KB}$ pathway, and NF- $\mathrm{kB}$ also controls the expression of various cytokines, particularly IL-6 and IL-8, which are strongly associated with tumor progression and CSC survival [51,52]. Extracellular IL-6 induces malignant features in stem/progenitor cells from ductal breast carcinoma [33]. In the tumor microenvironment, IL-8 overexpression promotes the acquisition of stemness, mesenchymal features, drug resistance, and the recruitment of immune-suppressive cells that facilitate tumor growth [53]. Novel therapeutics aimed at inhibiting IL-8 receptor signaling may halt tumor progression [54]. Machilin D decreased the secretory IL-6/IL-8 level (Figure 6) and inhibited mammosphere growth (Figure 7). Thus, this compound may be an anticancer agent that targets cancer and BCSCs.

\section{Conclusions}

An isolated compound was identified as machilin D by mass spectrometry and NMR. Machilin D inhibited the growth and mammosphere formation of breast cancer cells and inhibited tumor growth in a xenograft mouse model. Machilin D reduced the CD44 $4^{\text {high }} / \mathrm{CD} 24^{\text {low }}$ and ALDH1 cell fractions and the levels of Oct4, Nanog, c-Myc, and Sox2. Furthermore, this treatment reduced the nuclear localization of NF- $\mathrm{KB}$ p 65 and decreased the secretory IL-6 and IL-8 levels in mammospheres. These results suggest that machilin D blocks NF- $\mathrm{KB}$ and IL-6 and IL-8 signaling and induces CSC death. IL-6 and IL-8 regulation is important for breast CSC formation, and machilin D may be a potential agent targeting BCSCs. 
Supplementary Materials: Supplementary materials can be found at http://www.mdpi.com/2218-273X/10/2/245/s1.

Author Contributions: H.S.C. and X.Z. designed this study and participated in all the experiments, and H.S.C. and X.Z. wrote the manuscript. J.-H.K., S.-L.K., R.L., and B.-S.Y. helped design and perform the experiments. D.-S.L. supervised the study. All authors have read and agreed to the published version of the manuscript.

Funding: This research was supported by the Basic Science Research Program through the National Research Foundation of Korea (NRF) funded by the Ministry of Education (NRF-2016R1A6A1A03012862) and the Ministry of Trade, Industry, and Energy (MOTIE), Korea, under the "Regional Specialized Industry Development Program (R\&D, P0002062)" supervised by the Korea Institute for Advancement of Technology (KIAT).

Conflicts of Interest: The authors declare no conflict of interest.

\section{References}

1. Jung, Y.W.; Lee, B.M.; Ha, M.T.; Tran, M.H.; Kim, J.A.; Lee, S.; Lee, J.H.; Woo, M.H.; Min, B.S. Lignans from Saururus chinensis exhibit anti-inflammatory activity by influencing the Nrf2/HO-1 activation pathway. Arch. Pharm. Res. 2019, 42, 332-343. [CrossRef]

2. Cheng, Y.; Yin, Z.; Jiang, F.; Xu, J.; Chen, H.; Gu, Q. Two new lignans from the aerial parts of Saururus chinensis with cytotoxicity toward nasopharyngeal carcinoma. Fitoterapia 2019, 104344. [CrossRef]

3. Jin, Q.; Lee, J.W.; Kim, J.G.; Lee, D.; Hong, J.T.; Kim, Y.; Lee, M.K.; Hwang, B.Y. Lignans from Saururus chinensis with Inhibitory Effects on Nitric Oxide Production. J. Nat. Prod. 2019, 82, 3002-3009. [CrossRef] [PubMed]

4. Leask, A. A centralized communication network: Recent insights into the role of the cancer associated fibroblast in the development of drug resistance in tumors. Semin. Cell Dev. Biol. 2019. [CrossRef]

5. Zuo, Y.M.; Xu, Y.L.; Zhang, Z.L.; Liu, D.H.; Cai, M.T. Chemical Constituents from Saururus chinensis. Zhong Yao Cai 2015, 38, 2538-2540.

6. Moon, S.H.; Choi, S.W.; Park, S.J.; Ryu, S.Y.; Hwang, K.S.; Kim, C.H.; Kim, S.H. In vitro and in vivo Bone-Forming Activity of Saururus chinensis Extract. Phytother Res. 2015, 29, 1073-1080. [CrossRef]

7. Alaklabi, A.; Arif, I.A.; Ahamed, A.; Surendra Kumar, R.; Idhayadhulla, A. Evaluation of antioxidant and anticancer activities of chemical constituents of the Saururus chinensis root extracts. Saudi J. Biol. Sci. 2018, 25, 1387-1392. [CrossRef] [PubMed]

8. Moon, T.C.; Seo, C.S.; Haa, K.; Kim, J.C.; Hwang, N.K.; Hong, T.G.; Kim, J.H.; Kim, D.H.; Son, J.K.; Chang, H.W. Meso-dihydroguaiaretic acid isolated from Saururus chinensis inhibits cyclooxygenase-2 and 5-lipoxygenase in mouse bone marrow-derived mast cells. Arch. Pharm. Res. 2008, 31, 606-610. [CrossRef]

9. He, Z.; Dong, W.; Li, Q.; Qin, C.; Li, Y. Sauchinone prevents TGF-beta-induced EMT and metastasis in gastric cancer cells. Biomed. Pharmacother 2018, 101, 355-361. [CrossRef] [PubMed]

10. Bray, F.; Ferlay, J.; Soerjomataram, I.; Siegel, R.L.; Torre, L.A.; Jemal, A. Global cancer statistics 2018: GLOBOCAN estimates of incidence and mortality worldwide for 36 cancers in 185 countries. CA Cancer J. Clin. 2018, 68, 394-424. [CrossRef]

11. Garrido-Castro, A.C.; Lin, N.U.; Polyak, K. Insights into Molecular Classifications of Triple-Negative Breast Cancer: Improving Patient Selection for Treatment. Cancer Discov. 2019, 9, 176-198. [CrossRef] [PubMed]

12. Mustacchi, G.; De Laurentiis, M. The role of taxanes in triple-negative breast cancer: Literature review. Drug Des. Dev. Ther. 2015, 9, 4303-4318. [CrossRef] [PubMed]

13. La Belle, A.; Khatib, J.; Schiemann, W.P.; Vinayak, S. Role of Platinum in Early-Stage Triple-Negative Breast Cancer. Curr. Treat. Opt. Oncol. 2017, 18, 68. [CrossRef] [PubMed]

14. Park, S.Y.; Choi, J.H.; Nam, J.S. Targeting Cancer Stem Cells in Triple-Negative Breast Cancer. Cancers (Basel) 2019, 11, 965. [CrossRef]

15. Wu, H.J.; Chu, P.Y. Role of Cancer Stem Cells in Cholangiocarcinoma and Therapeutic Implications. Int. J. Mol. Sci. 2019, 20, 4154. [CrossRef]

16. Frank, N.Y.; Schatton, T.; Frank, M.H. The therapeutic promise of the cancer stem cell concept. J. Clin. Investig. 2010, 120, 41-50. [CrossRef]

17. Sridharan, S.; Howard, C.M.; Tilley, A.M.C.; Subramaniyan, B.; Tiwari, A.K.; Ruch, R.J.; Raman, D. Novel and Alternative Targets Against Breast Cancer Stemness to Combat Chemoresistance. Front. Oncol. 2019, 9, 1003. [CrossRef] 
18. Schulz, A.; Meyer, F.; Dubrovska, A.; Borgmann, K. Cancer Stem Cells and Radioresistance: DNA Repair and Beyond. Cancers (Basel) 2019, 11, 862. [CrossRef]

19. O'Conor, C.J.; Chen, T.; Gonzalez, I.; Cao, D.; Peng, Y. Cancer stem cells in triple-negative breast cancer: A potential target and prognostic marker. Biomark. Med. 2018, 12, 813-820. [CrossRef]

20. Kong, T.; Ahn, R.; Yang, K.; Zhu, X.; Fu, Z.; Morin, G.; Bramley, R.; Cliffe, N.C.; Xue, Y.; Kuasne, H.; et al. CD44 promotes PD-L1 expression and its tumor-intrinsic function in breast and lung cancers. Cancer Res. 2019. [CrossRef]

21. Attia, Y.M.; El-Kersh, D.M.; Ammar, R.A.; Adel, A.; Khalil, A.; Walid, H.; Eskander, K.; Hamdy, M.; Reda, N.; Mohsen, N.E.; et al. Inhibition of aldehyde dehydrogenase-1 and p-glycoprotein-mediated multidrug resistance by curcumin and vitamin D3 increases sensitivity to paclitaxel in breast cancer. Chem. Biol. Interact. 2019, 315, 108865. [CrossRef] [PubMed]

22. Koury, J.; Zhong, L.; Hao, J. Targeting Signaling Pathways in Cancer Stem Cells for Cancer Treatment. Stem Cells Int. 2017, 2017, 2925869. [CrossRef] [PubMed]

23. Vazquez-Santillan, K.; Melendez-Zajgla, J.; Jimenez-Hernandez, L.E.; Gaytan-Cervantes, J.; Munoz-Galindo, L.; Pina-Sanchez, P.; Martinez-Ruiz, G.; Torres, J.; Garcia-Lopez, P.; Gonzalez-Torres, C.; et al. NF-kappaBetainducing kinase regulates stem cell phenotype in breast cancer. Sci. Rep. 2016, 6, 37340. [CrossRef] [PubMed]

24. Choi, H.S.; Kim, S.L.; Kim, J.H.; Deng, H.Y.; Yun, B.S.; Lee, D.S. Triterpene Acid (3-O-p-Coumaroyltormentic Acid) Isolated From Aronia Extracts Inhibits Breast Cancer Stem Cell Formation through Downregulation of c-Myc Protein. Int. J. Mol. Sci. 2018, 19, 2528. [CrossRef]

25. Korkaya, H.; Liu, S.; Wicha, M.S. Regulation of cancer stem cells by cytokine networks: Attacking cancer's inflammatory roots. Clin. Cancer Res. 2011, 17, 6125-6129. [CrossRef]

26. Park, Y.H.; Kim, J.I.; Seo, S.Y.; Lee, E.; Kim, H.H. Saururus chinensis Baill inhibits proliferation and invasion of human renal cell carcinoma cells through inhibition of inhibitor of apoptosis protein. Chin. J. Integr. Med. 2016. [CrossRef]

27. Kim, Y.W.; Jang, E.J.; Kim, C.H.; Lee, J.H. Sauchinone exerts anticancer effects by targeting AMPK signaling in hepatocellular carcinoma cells. Chem. Biol. Interact. 2017, 261, 108-117. [CrossRef]

28. Clarke, M.L.; Burton, R.L.; Hill, A.N.; Litorja, M.; Nahm, M.H.; Hwang, J. Low-cost, high-throughput, automated counting of bacterial colonies. Cytometry A 2010, 77, 790-797. [CrossRef]

29. Choi, H.S.; Kim, D.A.; Chung, H.; Park, I.H.; Kim, B.H.; Oh, E.S.; Kang, D.H. Screening of breast cancer stem cell inhibitors using a protein kinase inhibitor library. Cancer Cell Int. 2017, 17, 25. [CrossRef]

30. Choi, H.S.; Kim, J.H.; Kim, S.L.; Deng, H.Y.; Lee, D.; Kim, C.S.; Yun, B.S.; Lee, D.S. Catechol derived from aronia juice through lactic acid bacteria fermentation inhibits breast cancer stem cell formation via modulation Stat3/IL-6 signaling pathway. Mol. Carcinog. 2018, 57, 1467-1479. [CrossRef]

31. Kim, S.L.; Choi, H.S.; Kim, J.H.; Jeong, D.K.; Kim, K.S.; Lee, D.S. Dihydrotanshinone-Induced NOX5 Activation Inhibits Breast Cancer Stem Cell through the ROS/Stat3 Signaling Pathway. Oxid. Med. Cell Longev. 2019, 2019, 9296439. [CrossRef] [PubMed]

32. Liang, Y.; Feng, G.; Wu, L.; Zhong, S.; Gao, X.; Tong, Y.; Cui, W.; Qin, Y.; Xu, W.; Xiao, X.; et al. Caffeic acid phenethyl ester suppressed growth and metastasis of nasopharyngeal carcinoma cells by inactivating the NF-kappaB pathway. Drug Des. Dev. Ther. 2019, 13, 1335-1345. [CrossRef] [PubMed]

33. Sansone, P.; Storci, G.; Tavolari, S.; Guarnieri, T.; Giovannini, C.; Taffurelli, M.; Ceccarelli, C.; Santini, D.; Paterini, P.; Marcu, K.B.; et al. IL-6 triggers malignant features in mammospheres from human ductal breast carcinoma and normal mammary gland. J. Clin. Investig. 2007, 117, 3988-4002. [CrossRef] [PubMed]

34. Choi, H.S.; Kim, J.H.; Kim, S.L.; Lee, D.S. Disruption of the NF-kappaB/IL-8 Signaling Axis by Sulconazole Inhibits Human Breast Cancer Stem Cell Formation. Cells 2019, 8, 1007. [CrossRef]

35. Kudela, E.; Samec, M.; Kubatka, P.; Nachajova, M.; Laucekova, Z.; Liskova, A.; Dokus, K.; Biringer, K.; Simova, D.; Gabonova, E.; et al. Breast Cancer in Young Women: Status Quo and Advanced Disease Management by a Predictive, Preventive, and Personalized Approach. Cancers (Basel) 2019, 11, 1791. [CrossRef]

36. Bardia, A.; Hurvitz, S. Targeted Therapy for Premenopausal Women with HR(+), HER2(-) Advanced Breast Cancer: Focus on Special Considerations and Latest Advances. Clin. Cancer Res. 2018, 24, 5206-5218. [CrossRef]

37. Siegel, R.L.; Miller, K.D.; Jemal, A. Cancer statistics, 2016. CA Cancer J. Clin. 2016, 66, 7-30. [CrossRef] 
38. Paluch-Shimon, S.; Pagani, O.; Partridge, A.H.; Abulkhair, O.; Cardoso, M.J.; Dent, R.A.; Gelmon, K.; Gentilini, O.; Harbeck, N.; Margulies, A.; et al. ESO-ESMO 3rd international consensus guidelines for breast cancer in young women (BCY3). Breast 2017, 35, 203-217. [CrossRef]

39. De Angelis, M.L.; Francescangeli, F.; Zeuner, A. Breast Cancer Stem Cells as Drivers of Tumor Chemoresistance, Dormancy and Relapse: New Challenges and Therapeutic Opportunities. Cancers (Basel) 2019, 11, 1569. [CrossRef]

40. Butti, R.; Gunasekaran, V.P.; Kumar, T.V.S.; Banerjee, P.; Kundu, G.C. Breast cancer stem cells: Biology and therapeutic implications. Int. J. Biochem. Cell Biol. 2019, 107, 38-52. [CrossRef]

41. Nobili, S.; Lapucci, A.; Landini, I.; Coronnello, M.; Roviello, G.; Mini, E. Role of ATP-binding cassette transporters in cancer initiation and progression. Semin. Cancer Biol. 2019. [CrossRef] [PubMed]

42. Liu, S.; Cong, Y.; Wang, D.; Sun, Y.; Deng, L.; Liu, Y.; Martin-Trevino, R.; Shang, L.; McDermott, S.P.; Landis, M.D.; et al. Breast cancer stem cells transition between epithelial and mesenchymal states reflective of their normal counterparts. Stem Cell Rep. 2014, 2, 78-91. [CrossRef] [PubMed]

43. Jeong, H.J.; Koo, B.S.; Kang, T.H.; Shin, H.M.; Jung, S.; Jeon, S. Inhibitory effects of Saururus chinensis and its components on stomach cancer cells. Phytomedicine 2015, 22, 256-261. [CrossRef] [PubMed]

44. Park, S.; Brugiolo, M.; Akerman, M.; Das, S.; Urbanski, L.; Geier, A.; Kesarwani, A.K.; Fan, M.; Leclair, N.; Lin, K.T.; et al. Differential Functions of Splicing Factors in Mammary Transformation and Breast Cancer Metastasis. Cell Rep. 2019, 29, 2672-2688 e7. [CrossRef] [PubMed]

45. Tentler, D.; Lomert, E.; Novitskaya, K.; Barlev, N.A. Role of ACTN4 in Tumorigenesis, Metastasis, and EMT. Cells 2019, 8, 1427. [CrossRef]

46. Sulaiman, A.; McGarry, S.; Han, X.; Liu, S.; Wang, L. CSCs in Breast Cancer-One Size Does Not Fit All: Therapeutic Advances in Targeting Heterogeneous Epithelial and Mesenchymal CSCs. Cancers (Basel) 2019, 11, 1128. [CrossRef]

47. Xia, Y.; Shen, S.; Verma, I.M. NF-kappaB, an active player in human cancers. Cancer Immunol. Res. 2014, 2, 823-830. [CrossRef]

48. Rinkenbaugh, A.L.; Baldwin, A.S. The NF-kappaB Pathway and Cancer Stem Cells. Cells 2016, 5, 16. [CrossRef]

49. Garner, J.M.; Fan, M.; Yang, C.H.; Du, Z.; Sims, M.; Davidoff, A.M.; Pfeffer, L.M. Constitutive activation of signal transducer and activator of transcription 3 (STAT3) and nuclear factor kappaB signaling in glioblastoma cancer stem cells regulates the Notch pathway. J. Biol. Chem. 2013, 288, 26167-26176. [CrossRef]

50. Wu, D.; Jin, S.; Lin, Z.; Chen, R.; Pan, T.; Kang, X.; Huang, H.; Lin, C.; Pan, J. Sauchinone inhibits IL-1beta induced catabolism and hypertrophy in mouse chondrocytes to attenuate osteoarthritis via Nrf2/HO-1 and NF-kappaB pathways. Int. Immunopharmacol. 2018, 62, 181-190. [CrossRef]

51. Song, L.; Liu, L.; Wu, Z.; Li, Y.; Ying, Z.; Lin, C.; Wu, J.; Hu, B.; Cheng, S.Y.; Li, M.; et al. TGF-beta induces miR-182 to sustain NF-kappaB activation in glioma subsets. J. Clin. Investig. 2012, 122, 3563-3578. [CrossRef] [PubMed]

52. Parajuli, P.; Anand, R.; Mandalaparty, C.; Suryadevara, R.; Sriranga, P.U.; Michelhaugh, S.K.; Cazacu, S.; Finniss, S.; Thakur, A.; Lum, L.G.; et al. Preferential expression of functional IL-17R in glioma stem cells: Potential role in self-renewal. Oncotarget 2016, 7, 6121-6135. [CrossRef] [PubMed]

53. Dominguez, C.; McCampbell, K.K.; David, J.M.; Palena, C. Neutralization of IL-8 decreases tumor PMN-MDSCs and reduces mesenchymalization of claudin-low triple-negative breast cancer. JCI Insight 2017, 2, e94296. [CrossRef] [PubMed]

54. Singh, J.K.; Simoes, B.M.; Howell, S.J.; Farnie, G.; Clarke, R.B. Recent advances reveal IL-8 signaling as a potential key to targeting breast cancer stem cells. Breast Cancer Res. 2013, 15, 210. [CrossRef] [PubMed]

(C) 2020 by the authors. Licensee MDPI, Basel, Switzerland. This article is an open access article distributed under the terms and conditions of the Creative Commons Attribution (CC BY) license (http://creativecommons.org/licenses/by/4.0/). 